\title{
Pemberdayaan Masyarakat Miskin di Bantaran Kali Ciliwung
}

\author{
Dormiana Yustina Manurung
}

\begin{abstract}
Abstrak
Masyarakat miskin yang tinggal di bantaran Kali Ciliwung sudah lama mengalami beragam persoalan sosial, dari serangan banjir, keterbatasan kesempatan kerja, hingga ancaman penggusuran. Namun, melalui pendampingan Yayasan Ciliwung Merdeka (YCM), masyarakat bantaran Kali Ciliwung mampu bertahan dalam memenuhi kebutuhan hidup sehari-hari, membangun sistem komunal, mengembangkan usaha informal, serta menciptakan pola hidup yang dinamis. Karenanya, YCM memiliki peran penting dalam pemberdayaan masyarakat melalui penyelenggaraan program-program sosial dalam dimensi luas, yang meliputi kegiatan kesehatan, pendidikan, pemberdayaan ekonomi, kesenian dan kebudayaan, serta aksi peduli lingkungan. Dengan modal dan jaringan sosial yang dimiliki YCM, masyarakat di bantaran Kali Ciliwung mampu menjadi mandiri dan produktif. Tulisan ini akan mengkaji dinamika dan relasi sosial masyarakat miskin yang tinggal di bantaran Kali Ciliwung.
\end{abstract}

Key words: social capital, trust, networking, community development, civil society.

\section{Pendahuluan}

Pola pembangunan yang bersifat top-down sudah lama dan masih cenderung diterapkan di Indonesia, bahkan dalam sistem desentralisasi saat ini. Pembangunan topdown ini didasarkan pada perencanaan pertumbuhan ekonomi dan mengabaikan dimensi sosial, serta cenderung mengeksklusi kepentingan kelas bawah. Dalam konteks Jakarta, salah satu kelas sosial yang tereksklusi adalah masyarakat yang tinggal di bantaran Kali Ciliwung. Sebagai kelompok marginal, penduduk ini dianggap hanya sebagai pengganggu pembangunan yang perlu ditertibkan demi kenyamanan bersama.

Dianggap sebagai sumber penyebab banjir, Kali Ciliwung menjadi fokus perhatian perancang kebijakan pembangunan Jakarta. Kali Ciliwung sudah tidak mampu menampung limpahan air dan limbah dari berbagai industri dan pemukiman di sepanjang alirannya. Dari semua sungai yang mengalir di Jakarta, Ciliwung memiliki dampak yang paling luas ketika musim hujan, karena mengalir melintasi tengah Kota Jakarta, melalui banyak perkampungan, perumahan, dan pemukiman kumuh. Sungai ini mengalir sepanjang 120 kilometer melintasi Bogor, Depok dan Jakarta. Selain kerusakan Daerah Aliran Sungai (DAS) di bagian hulu (Puncak dan Bogor), besarnya potensi banjir juga disebabkan penyempitan dan pendangkalan DAS di bagian hilir (Jakarta).

Bukit Duri dan Kampung Pulo merupakan penghuni bagian hilir Kali Ciliwung, yang tidak hanya mengalami kesulitan mengakses air bersih, tetapi juga rawan terkena penyakit-penyakit yang disebabkan oleh banjir. Meski demikian, tidak sedikit masyarakat yang memilih untuk membangun kehidupannya di sekitar aliran sungai ini, dan bahkan membentuk sebuah komunitas untuk saling bekerja sama dalam menghadapi berbagai 
permasalahan. Sejak dulu, warga Bukit Duri memupuk rasa kebersamaan dan membangun pola perekonomian yang dinamis dalam sektor informal. Meski menghadapi berbagai persoalan, warga tetap hidup harmonis, saling mendukung dan bekerjasama.

Sementara upaya pemerintah dalam menangani banjir ini lebih banyak terfokus pada sistem infrastruktur sungai, mulai pelebaran sungai, pengerukan sungai, membuat codetan sungai, hingga membuat kanal tambahan untuk menyalurkan limpahan air yang berlebih di sungai-sungai utama di Jakarta. Solusi yang dilakukan pemerintah DKI Jakarta sering menimbulkan masalah baru dan menuai berbagai protes, bukan hanya karena kebijakan pemerintah tidak melibatkan warga dalam pengambilan keputusan, tetapi juga karena penekanannya pada ketertiban dan keamanan berujung pada penggusuran.

Warga di bantaran Kali Ciliwung lebih mengkhawatirkan adanya penggusuran atau relokasi oleh pemerintah DKI Jakarta, ketimbang adanya banjir yang melanda wilayah itu. Sebab, lokasi itu menjadi satu-satunya tumpuan warga dalam mencari penghidupan. Warga di bantaran Kali Ciliwung tidak mampu membayangkan bagaimana memperoleh pendapatan di tempat lain setelah direlokasi. Begitu pula warga Bukit Duri dan Kampung Pulo yang menjadi fokus kajian dalam artikel ini. Sejak dulu, warga Bukit Duri dan Kampung Pulo membangun pola perekonomian yang dinamis di sektor informal, disebabkan letaknya yang strategis, yakni berdekatan dengan Pasar Jatinegara, tiga stasiun kereta api (Jatinegara, Tebet dan Manggarai), serta terminal Kampung Melayu. Kondisi warga yang berada dalam garis kemiskinan hanya memungkinkan mereka untuk mengembangkan perekonomian di sektor informal.

Masyarakat yang berpenghasilan rendah mengembangkan beragam usaha yang tak dihitung sebagai pekerjaan resmi, seperti menjual sayuran, membuka kedai kopi, warung nasi, jasa mencuci baju, pemotongan ayam, usaha sapu lidi, dan sebagainya. Usaha-usaha informal ini dapat bersirkulasi dengan dinamis pada pusat-pusat perekonomian yang tidak jauh dari tempat tinggal mereka, seperti Pasar Jatinegara, stasiun kereta api, serta terminal Kampung Melayu. Tulisan ini akan mengelaborasi bagaimana masyarakat miskin yang tinggal di bantaran Kali Ciliwung mampu bertahan dan membangun pola kehidupan yang dinamis dalam berbagai keterancaman sosial, seperti serangan banjir dan penggusuran, melalui pendampingan Yayasan Ciliwung Merdeka.

\section{Ancaman Penggusuran}

Penggusuran selalu menjadi isu menakutkan yang menghantui warga di sekitar bantaran Kali Ciliwung. Setelah banjir besar menimpa Jakarta pada tahun 2007, wacana pembenahan Kali Ciliwung semakin menguat, terutama dengan adanya kerjasama antara pemerintah dan Bank Dunia untuk mengeruk Kali Ciliwung pada tahun 2008. Proyek pengerukan ini disebut dengan Jakarta Emergency Dredging Initiative (JEDI). 
Siti Khoirun Nikmah (2010), peneliti Infid (International NGO Forum on Indonesian Development), mengungkapkan bahwa terdapat dua tujuan utama dari JEDI yang didasarkan pada dokumen Bank Dunia. Pertama, mengurangi dampak banjir tahunan di DKI melalui perbaikan dan pengerukan jalur banjir, saluran air, dan waduk berdasarkan standard internasional. Kedua, menyediakan tenaga ahli melalui pelatihan untuk memperkuat kapasitas Pemerintah DKI Jakarta dan Kementerian Pekerjaan Umum dalam mengoperasikan dan merawat sistem pengendalian bajir berdasarkan standard internasional. Sejak awal, penggunaan standard internasional ditekankan dalam dokumen proyek JEDI. Bahkan penerapan standar internasional ini berkonsekuensi pada pemindahan paksa atau penggusuran pemikiman kumuh yang berada di bantaran Kali Ciliwung. Disebutkan dalam dokumen Bank Dunia bahwa sekitar 5.450 tempat tinggal perlu digusur demi menyukseskan proyek JEDI.

Oleh karena itulah warga yang tinggal di bantaran Kali Ciliwung semakin diresahkan oleh rencana penggusuran tersebut. Warga bukannya menolak penggusuran, tetapi meminta pemerintah daerah untuk melibatkan mereka dalam mengambil menentukan dan kebijakan, terutama dalam merumuskan nasib perekonomian mereka setelah pindah lokasi. Namun, di hadapan pemerintah, warga nampaknya ditempatkan dalam posisi lemah, terutama yang berkaitan dengan status tanah, karena rata-rata penduduk yang tinggal di bantaran sungai hanya memiliki surat girik bukan sertifikat tanah. Sebab kondisi perekonomian memang tidak memungkinkan mereka untuk mengurus sertifikat tanah dengan biaya tambahan. Ketiadaan sertifikat tanah dijadikan alasan pemerintah untuk menggusur pemukiman warga, dengan alasan bahwa status tinggal warga adalah ilegal.

Berdasarkan penelitian yang dilakukan Siti Khoirun Nikmah (2010), setidaknya terdapat dua persoalan yang dijadikan alasan penggusuran oleh Pemda DKI Jakarta: (1) ketiadaan legalitas formal atas tanah pemukiman warga; dan (2) tidak dimilkinya Kartu Tanda Penduduk (KTP) DKI Jakarta. Meski demikian, menguatnya wacana demokrasi nampaknya berkonstribusi positif terhadap kepentingan warga di bantaran Kali Ciliwung. Meski pembangunan masih bersifat elitis, pemerintah tidak berani lagi menggunakan cara paksa. Pemerintah cenderung berupaya mempertahankan citranya sebagai "pro-rakyat" dalam melegitimasi kekuasaannya, terutama ketika media turut serta memprotes kebijakan penggusuran. Penggusuran tidak lagi menjadi pendekatan pemerintah, tetapi lebih cenderung dilakukan pendekatan relokasi secara pelan-pelan.

Misalnya, dalam rencana Pemerintah DKI Jakarta 2012-2014 tentang pelebaran sungai Ciliwung menjadi 50 meter, pemerintah DKI Jakarta membuat program untuk merelokasi warga di sekitar bantaran Kali Ciliwung ke Rusunawa di kawasan Berlan, Matraman, Jakarta Timur, dengan berbagai biaya yang ditanggungkan kepada warga, seperti sewa rumah, listrik dan air, yang tentu saja kebijakan tersebut menuai protes karena berada di luar kemampuan mereka. Selain itu, warga juga belum bisa memastikan atau 
masih mengkhawatirkan tidak adanya pekerjaan baru, tidak tersedianya pendidikan bagi anak-anak mereka, serta sulitnya layanan kesehatan yang terjangkau seperti yang difasilitasi oleh Yayasan Ciliwung Merdeka.

Namun, terpilihnya pemerintahan Jokowi-Ahok setidaknya membawa harapan baru bagi warga Bukit Duri dan Kampung Pulo. Pada 16 Oktober 2012, Jokowi mendatangi Sanggar Ciliwung Merdeka dan mendengar paparan Sandyawan, pendiri komunitas Ciliwung Merdeka, tentang rencana pembangunan Kampung Susun Manusiawi Bukit Duri. Setelah itu Jokowi juga menjanjikan dukungannya untuk melaksanakan rancangan pembangunan itu. Meski demikian, dengan berbagai pertimbangan pendanaan, nampaknya rencana pembangunan ini masih sulit dilaksanakan, terbukti dengan tetap digunakannya pendekatan relokasi secara berlahan oleh pemerintah DKI Jakarta.

\section{Peran Yayasan Ciliwung Merdeka}

Berbagai protes dan penolakan terhadap kebijakan pemerintah sering dilakukan oleh beberapa komunitas yang ada di bantaran Kali Ciliwung. Salah satunya adalah Yayasan Ciliwung Merdeka, yang didirikan oleh Sandyawan Sumardi pada tanggal 13 Agustus 2000. Komunitas ini memiliki program-program sendiri dalam pemberdayaan masyarakat di Bukit Duri dan Kampung Pulo, yang mendapatkan respon positif dari warga setempat, dengan pendekatannya yang melibatkan warga secara aktif.

Yayasan Ciliwung Merdeka (YCM) adalah sebuah wahana gerakan kemanusiaan yang anggotanya meliputi anak, remaja dan warga Bukit Duri bantaran Kali Ciliwung RT 005, 006, 007, 008 RW 012, Kel. Bukit Duri Tebet, Jakarta Selatan, dan Kampung Pulo RT 009, 010, 011 RW 003 Kel. Kampung Melayu Jatinegara, Jakarta Timur. Program-program YCM diselenggarakan untuk menghadapi tantangan utama kehidupan anak, remaja dan warga Bukit Duri, terutama dalam mengatasi berbagai persoalan ekonomi, politik, sosial dan budaya.

YCM memiliki misi untuk membuka, meningkatkan kesadaran kritis, pengetahuan dan ketrampilan, serta sikap keswadayaan dan solidaritas masyarakat di Bukit Duri dan Kampung Pulo. Selain itu, warga Bukit Duri dan Kampung Pulo berperan aktif, baik sebagai pelaksana maupun peserta, dalam program-program yang difasilitasi oleh YCM. Dalam beberapa hal warga terlibat aktif dalam merancang dan menentukan program-program yang disesuaikan dengan kebutuhan mereka, seperti program kesehatan secara saweran, pengembangan aktivitas seni budaya, dan sebagainya.

Sudah sebelas tahun lebih warga Bukit Duri dan Kampung Pulo didampingi dan difasilitasi oleh Yayasan Ciliwung Merdeka melalui program-program pemberdayaan, terutama dalam penumbuhan kesadaran, solidaritas dan sikap swadaya komunitas untuk mewujudkan perubahan kualitas hidup mereka. Semua kegiatan dilakukan berdasarkan kesepakatan dan keterlibatan aktif warga. Rembug Warga sebagai media berdiskusi adalah 
bagian yang tak terpisahkan dalam kegiatan yang digalang dan didampingi oleh Yayasan Ciliwung Merdeka.

Secara garis besar, terdapat tujuh program pemberdayaan yang dikembangkan oleh Yayasan Ciliwung Merdeka dan terus berlangsung hingga saat ini. Pertama, pendidikan alternatif. Oleh karena mahalnya pendidikan formal yang tidak mampu ditanggung oleh sebagian besar masyarakat miskin, Yayasan Ciliwung Merdeka menfasilitasi kebutuhan pendidikan anak dan remaja Bukit Duri dan Kampung Pulo dengan mengembangkan sistem belajar mandiri di Sanggar Ciliwung. Sistem pendidikan yang dikembangkan lebih bersifat saling membantu di antara para pelajar. "Yang tua mengajari yang lebih muda, yang SMP mengajari yang SD, yang SMA mengajari yang SMP, yang di perguruan tinggi mengajari yang SMA, juga banyak teman-teman relawan yang peduli mengajari mereka," ujar Sandyawan Sumardi. Kegiatan pembelajaran mandiri yang diselenggarakan cukup beragam, mulai menggambar, mewarnai, dokter kecil, rumah kompos, belajar bahasa Inggris, musik, teater, dan sebagainya.

Kedua, pendidikan swadaya kesehatan masyarakat. Tujuan Pendidikan Swadaya Kesehatan Masyarakat adalah membuka, meningkatkan kesadaran kritis, menambah pengetahuan dan melatih keterampilan, serta menumbuhkan sikap keswadayaan dan solidaritas di bidang kesehatan secara mandiri di Bukit Duri dan Kampung Pulo. Selain itu, dikembangkan praktek pelayanan kesehatan umum, gigi, akupuntur, serta pendidikan pelatihan tanaman obat herbal dan apotik hidup.

Dalam menfasilitasi pengobatan penduduk miskin, YCM membangun klinik khusus bagi warga Bukit Duri dan Kampung Pulo, dengan mengajak beberapa dokter yang peduli terhadap kondisi masyarakat miskin untuk turut membantu pengobatan warga tanpa pungutan biaya, sehingga warga Bukit Duri dan Kampung Pulo dapat memeriksa dan mengobati penyakit ringan hanya dengan uang pendaftaran berobat sebesar Rp. 1.000,-. "Sebenarnya, banyak dokter yang mau bekerjasama membantu warga miskin di sini," ungkap Sandyawan Sumardi. Namun, untuk penyakit berat yang tidak dapat diatasi di klinik, warga tetap harus menanggung biaya sendiri yang tentunya berada di luar kemampuan mereka, sehingga sering warga menggalang dana (saweran) untuk membantu biaya pengobatan sesama warga yang tidak mampu. Selain itu, warga Bukit Duri dan Kampung Pulo juga berinisiatif membayar iuran "Dana Solidaritas Sehat" sebesar Rp. 1.000,-/Bulan. Keterbatasan ekonomi yang mereka alami ternyata mendorong mereka untuk membangun solidaritas komunal.

Ketiga, pendidikan lingkungan hidup. Salah satu persoalan yang rumit ditangani adalah penanganan sampah. Selain menyebarkan penyakit, tumpukan sampah juga dapat mengganggu kenyamanan warga bila dibiarkan berlarut-larut. Yayasan Ciliwung Merdeka juga mengajak warga untuk mengolah sampah (daur ulang) menjadi pupuk tanaman atau produk-produk lainnya yang dapat berguna. Pola pendidikan dan pemberdayaan ini tidak 
hanya berupaya membenahi persoalan sampah yang mengganggu di sekitar pemukiman warga, tetapi juga demi meningkatkan produktivitas warga.

Dalam dokumen pengelolaan sampah yang diselenggarakan oleh Yayasan Ciliwung Merdeka, dinyatakan bahwa praktik daur ulang ini memiliki beberapa manfaat, di antaranya: (1) mengurangi sampah yang akan dibuang ke TPA, sehingga dapat menekan biaya angkut; (2) meningkatkan peran aktif masyarakat dalam pengelolaan sampah sebagai mitra pemerintah; (3) meningkatkan efisiensi pengelolaan sampah, serta mengurangi beban pencemaran akibat Open Damping di TPA; (4) meningkatkan lapangan kerja bagi masyarakat sekitar dalam melakukan proses daur ulang dengan menggunakan teknologi yang sederhana dan mudah dioperasikan; (5) memberikan manfaat ekonomi dari hasil penjualan produk-produk daur ulang sampah; serta (6) meningkatkan kebersihan lingkungan yang berakibat pula pada meningkatnya kesehatan serta kualitas lingkungan tempat masyarakat tinggal.

Keempat, pendidikan swadaya ekonomi masyarakat. Warga Bukit Duri dan Kampung Pulo banyak bergantung pada perekonomian dalam sektor informal sebagai satu-satunya cara untuk bertahan hidup. Karenanya, Yayasan Ciliwung Merdeka mengembangkan pemberdayaan ekonomi yang berbasis pada pendidikan dan pelatihan swadaya ekonomi masyarakat. Sehingga warga Bukit Duri dan Kampung Pulo mampu meningkatkan kreativitas dan produktivitas mereka dalam menghasilkan berbagai komoditas, seperti tas, keset, pupuk, lemari, dan sebagainya. Pengembangan swadaya ekonomi informal tersebut didukung oleh lokasi Bukit Duri dan Kampung Pulo yang strategis: dalam radius $\pm 1-2$, terdapat Pasar Jatinegara, tiga stasiun kereta api (Jatinegara, Tebet dan Manggarai), serta terminal Kampung Melayu.

Kelima, pendidikan seni budaya rakyat. Selain pemberdayaan di bidang ekonomi dan kesehatan, Yayasan Ciliwung Merdeka juga memberdayakan kesadaran kritis warga, terutama anak-anak dan remaja, melalui gerakan sosial-kebudayaan, yang secara spesifik dalam wujud pementasan sinergis antara teater, tari, musik dan audio-visual, sehingga anakanak, remaja dan seluruh warga, mampu mendayagunakan energi-energi potensial yang mereka miliki. Salah satu pementasan budaya pernah digelar di Taman Ismail Marzuki pada 5-6 Juli 2011. Pementasan Budaya Teater Musikal yang disutradarai Sandyawan Sumardi ini dimainkan oleh sekitar 75 warga komunitas bantaran sungai Ciliwung di Bukit Duri dan Kampung Pulo, yang terdiri dari anak-anak, remaja, ibu-ibu, dan juga bapak-bapak. Teater Musikal ini mengisahkan perjuangan warga miskin sehari-hari.

Keenam, pusat latihan daya pinggir. Pemberdayaan masyarakat melalui pelatihan keterampilan-keterampilan tambahan sangat penting sebagai upaya strategis untuk bertahan hidup. Pusat latihan daya pinggir yang dibangun oleh Yayasan Ciliwung Merdeka dimaksudkan untuk memberikan keterampilan-keterampilan tambahan bagi warga, seperti memperbaiki barang-barang elektronik yang sudah rusak, membuat beragam macam masakan, persiapan menghadapi banjir dan sebagainya. Dengan adanya Pusat Latihan Daya 
Pinggir ini masyarakat mampu mengembangkan potensinya dan menjadi lebih mandiri. Mengembangan potensi-potensi individual ini penting bagi warga miskin untuk dapat menghemat biaya hidup, sehingga mereka tidak terlalu bergantung pada penyedia jasa-jasa eksternal yang tentu saja membutuhkan pengeluaran dana tambahan.

Ketujuh, pendidikan tata ruang kampung swadaya. Kenyamanan Kampung merupakan salah satu prioritas yang diupayakan oleh warga Bukit Duri dan Kampung Pulo. Kenyamanan tersebut terkait dengan penataan ruang kampung secara mandiri. Dalam hal inilah Yayasan Ciliwung Merdeka menfasilitasi warga untuk aktif terlibat dalam mendesain tata ruang sehingga lebih rapi dan teratur. Selain itu, beberapa arsitektur pernah meneliti desain bangunan di Bukit Duri dan memberikan saran desain tata ruang alternatif yang lebih bersahabat dengan warga sekitar, seperti desain bangunan yang tahan banjir dan ramah lingkungan. Namun, usulan desain pembangunan tata ruang alternatif tersebut masih sulit dilaksanakan karena tidak adanya respon dari pemerintah sebagai pemegang otoritas. Salah satu yang bisa dilakukan warga setempat hanyalah memperindah bangunan yang mereka miliki, misalnya dengan mengatur penempatan ruang dan melukis dinding depan rumah dengan beragam kreatifitas, sehingga bangunan-bangunan di kampung nampak lebih indah dan nyaman ditempati. Proses penataan ruang tersebut dilakukan dengan semangat gotong royong dan kerja sama di antara warga.

\section{Modal Sosial dan Solidaritas Komunal}

Seringnya banjir yang datang membuat warga Bukit Duri dan Kampung Pulo lebih waspada dan bekerja sama untuk mengantisipasi dan mengatasi dampak terjadinya banjir. Pemilik warung makan terbiasa membungkus dan mengamankan barang-barangnya dengan terpal, yang biasanya ditempatkan di ruang kosong di bawah atap rumah sebagai penyimpanan sementara saat banjir datang. Namun, kewaspadaan saja ternyata belum cukup. Terkadang banjir datang di luar dugaan, dan bahkan genangan air pernah bertahan hingga seminggu, sehingga banyak alat elektronik yang rusak. Sehingga masyarakat pun perlu lebih bersiaga. Kondisi itulah yang membuat warga Bukit Duri dan Kampung Pulo membentuk Posko Tanggap Darurat Bukit Duri pada tahun 2002. Posko swadaya ini dibentuk melalui semangat gotong-royong.

Salah satu antisipasi banjir, seperti dinyatakan Abdul Muiz, seorang penggiat Ciliwung Merdeka, adalah dilakukannya koordinasi secara rutin dengan penjaga pintu air Katulampa, sehingga warga biasanya sudah mendapat informasi banjir dua hari sebelumnya. Pengumuman tentang datangnya banjir disebarkan melalui pengeras suara di musholamushola. Selain itu, masyarakat juga membaca tanda-tanda alam yang menunjukkan akan datangnya banjir, seperti keluarnya kecoa dan tikus yang mencari tempat aman. Dengan adanya antisipasi banjir inilah warga menjadi lebih sigap dalam berkoordinasi untuk mengatasi berbagai kemungkinan yang akan terjadi. 
Sebagian warga mengungsi ke dataran yang lebih tinggi. Ada yang mengungsi di mesjid dan posko tanggap darurat, meski ada pula yang memilih bertahan di rumah masing-masing. Tak sedikit warga yang bersedia merelakan rumahnya sebagai tempat pengungsian. Setelah mendengar pengumuman, Posko bekerja secara spontan. Terdapat pula tim pencari dan penyelamat, yang berangggotakan anak-anak muda berumur 15 hingga 27 tahun. Tugas mereka memberikan bantuan darurat bagi warga yang terlambat menghindari banjir. Dengan menggunakan perahu karet, mereka mendatangi lokasi banjir. Selain mendistribusikan makanan siap saji, tim penyelamat ini juga memantau perkembangan banjir. Sebagian warga menjadi tim konsumsi, dan sebagian lagi menjadi tim kesehatan, lengkap dengan obat-obatan medis pertolongan pertamanya. Seperti dinyatakan Abdul Muiz, tim kesehatan Ciliwung merdeka bergerak mendatangi tempattempat pengungsian banjir untuk menemukan warga yang membutuhkan pertolongan medis. Awalnya, tim medis mendata persediaan obat-obatan di klinik Ciliwung Merdeka, serta menghubungi dokter-dokter relawan yang bersedia membantu. Tim medis mendatangi lokasi-lokasi banjir dengan memakai gerobak motor (mobile klinik) sebagai pengangkut obat-obatan. Pengobatan ini diberikan secara gratis bagi warga yang membutuhkan. Selain pengobatan, para relawan juga membuka Pos Trauma Healing untuk anak-anak, yang diisi dengan kegiatan pertunjukan sulap dan musik.

Francis Fukuyama (2001) memaknai modal sosial sebagai nilai-nilai yang memungkinkan setiap individu dalam masyarakat untuk bergabung dan bekerjasama, dengan mengabaikan kepentingan pribadi, untuk memenuhi kebutuhan kolektif. Karenanya, modal sosial dapat dipandang sebagai aspek budaya yang mewujud dalam relitas sosial dan memiliki peran penting dalam kesuksesan pembangunan sosial. Sementara Putnam (1992) mengatakan bahwa modal sosial merupakan fitur dari organisasi sosial yang berupa jaringan keterikatan sosial (networks of civic engangement) yang diatur oleh sistem nilai tertentu dalam memfasilitasi koordinasi dan kerjasama untuk mendapatkan keuntungan bersama.

\section{Relasi Stakeholders dan Civil Society}

Kongstad dan Monsted, seperti dikutip John Martinussen (1997), menekankan bahwa ruang komunal dan aktivitas-aktivitas informal memiliki peran penting sebagai tumpuan hidup masyarakat miskin, yang tidak boleh diabaikan dalam pembangunan sosial dan pengembangan civil society. Oleh karenanya, dalam pelaksanaan program-program yang bersinambungan, Yayasan Ciliwung Merdeka (YCM) butuh menjaga hubungan baik dengan para stakeholder, yang terdiri dari komponen masyarakat, organisasi donor, serta tentunya dengan pemerintah DKI Jakarta. Patut diakui, tidak semua program YCM dapat berjalan optimal, seperti kegiatan daur ulang sampah, yang selain dikarenakan masalah teknik perencanaan program, namun juga disebabkan keterbatasan relasional dengan para pihak-pihak pendukungnya. 
Keberadaan YCM dalam komunitas masyarakat di bantaran Kali Ciliwung ini terbilang cukup mengakar, tecermin dari intensitas penyelenggaraan program, serta diterimanya program-program pemberdayaan selama ini. Masyarakat juga menaruh kepercayaan yang cukup tinggi kepada YCM, sebagaimana ditunjukkan dengan seringnya YCM menjadi media yang menfasilitasi pemberdayaan, pendampingan serta komunikasi bagi kebijakan-kebijakan pemerintah yang baru diterapkan. Terdapat pola hubungan timbal balik yang seimbang antara YCM dan warga, di mana satu sama lain saling percaya dan memiliki dependensi yang kuat serta padu. Beberapa program YCM bahkan bersumber dari masyarakat setempat, seperti pola saweran bagi program kesehatan, pengembangan aktivitas kesenian dan pengelolaan dana pendidikan beasiswa yang dibentuk secara mandiri.

Khusus untuk lembaga donor, hubungannya bersifat temporer, berlangsung berdasarkan program yang dijalankan dan bukan berskala jangka panjang. Mereka membantu sumbangan dana (khususnya dari perseorangan) serta penyediaan saranaprasarana program. Donor ini tidak bersifat mengikat. Namun, YCM tidak sepenuhnya menggantungkan pembiayaan dan kebersinambungan programnya melalui donor. YCM sedapat mungkin berusaha secara mandiri dan mendorong partisipasi masyarakat.

Sementara itu, relasi YCM dan media cukup menarik. Selama ini YCM yang diprakarsai oleh Sandyawan ini mendapat liputan media yang cukup banyak, bukan hanya dari dalam namun juga luar negeri. Para wartawan tersebut mendapat fasilitas internship selama beberapa waktu guna mengamati kondisi di lapangan. Selama proses tersebut para wartawan berinteraksi dengan masyarakat, mengamati jalannya program, serta berkesempatan turut dalam implementasi kegiatan-kegiatannya. Hal ini memungkinkan terciptanya kesepahaman gagasan, tujuan dan pandangan atas manfaat dari penerapan program-program ini. Dalam kondisi ini, tercipta relasi yang positif, mendorong publikasi kegiatan sehingga meningkatkan kepercayaan (trust) terhadap YCM, yang giliran berikutnya berkembang sebagai modal sosial yang penting.

Namun, patut disayangkan, berbeda dengan relasi terhadap aktor-aktor lainnya, hubungan dengan pemerintah terbilang kurang optimal. Data lapangan dan wawancara menyebutkan bahwa pemerintah selama ini belum memperhatikan keberadaan YCM, tecermin dari hampir tidak ada kunjungan dan tinjauan pemerintah DKI Jakarta, baik terhadap YCM maupun warga di bantaran Kali Ciliwung, terutama pada masa-masa awal kehadiran YCM. Hanya pada pemerintahan Jokowi-Ahok saja dilakukan beberapa kunjungan dan sharing persoalan warga, namun masih belum terdapat titik temu dalam menentukan bentuk dan pola pembangunan sosial antara pemerintah DKI Jakarta dan YCM.

Lain dari itu, jembatan komunikasi atas kebijakan-kebijakan pemerintah dengan kepentingan masyarakat tidak terbangun, seperti mediasi atas normalisasi sungai yang akan merelokasi pemukiman penduduk. Dalam persoalan inilah YCM berperan besar dalam mengadvokasi warga Bukit Duri dan Kampung Pulo mengenai program-program 
pemerintah yang berhubungan dengan kelangsungan komunitas tersebut, serta mengadvokasi pemerintah mengenai usulan-usulan yang muncul dari masyarakat mengenai programprogram tersebut. Sayangnya, proses advokasi itu belum berhasil menemukan titik tengah. YCM sama sekali kurang mendapatkan bantuan atau pun dukungan dari pemerintah. Bahkan, masukan-masukan konstruktif atas rencana pembangunan kampung bantaran sungai, yang rancangannya telah digagas secara mandiri oleh warga, kurang mendapatkan tanggapan positif dari pemerintah.

Selama ini YCM telah menyampaikan berbagai aspirasi warga Bukit Duri dan Kampung Pulo terhadap rencana Pemerintah DKI untuk normalisasi Kali dan Tata Kelola Kota untuk dipertimbangkan oleh Pemerintah DKI, hanya saja tidak pernah ada tindak lanjut dari Pemerintah mengenai usulan tersebut. Artinya, upaya advokasi tersebut hanya dilakukan kepada masyarakat dampingan dan belum berhasil mengadvokasi pemerintah untuk mempertimbangkan aspirasi masyarakat.

Mohanty (1995) menegaskan pentingnya komitmen dalam membuka ruang partisipasi masyarakat, sehingga diharapkan terjadi keterbukaan institusi publik, pemberdayaan dan penguatan kemampuan, serta peluang masyarakat sipil dalam mengembangkan sumberdaya dan kegiatannya. Begitu pula Schneider dan Libercier (1995) menyatakan bahwa partisipasi dari beragam kalangan masyarakat merupakan upaya untuk membangun kepercayaan diri aktor pembangunan melalui dialog dan sikap tanggap, serta mempersiapkan kemampuan yang dibutuhkan demi menyongsong pembangunan sosial dan ekonomi.

Kehadiran Yayasan Ciliwung Merdeka memperlihatkan hubungan yang padu antara pemberdayaan komunitas, kesadaran lingkungan, serta gagasan membangun kualitas hidup manusia dalam aneka dimensinya (ekonomi, kesehatan, pendidikan, serta sosial). Hal ini tecermin dari implementasi program-programnya sebagaimana terurai pada bagian sebelumnya, yang bila ditelaah lebih lanjut, menunjukan keselarasan dengan konsep community development dan civil society yang bertujuan meningkatkan kesejahteraan ekonomi masyarakat, memperhatikan kelestarian lingkungan, serta berdampak pada kehidupan sosial setempat.

\section{Rekomendasi Pembangunan Sosial}

Kiprah Yayasan Ciliwung Merdeka (YCM) selama beberapa kurun waktu ini mencerminkan pula usaha pemberdayaan yang bersifat bottom up, mengedepankan prinsip partisipasi dari komunitas lokal, baik melalui dialog aktif maupun pelibatan masyarakat dalam setiap penyelenggaraan programnya. Akan tetapi, sebagaimana umumnya aktivitas sosial nirlaba, kegiatan-kegiatan Yayasan Ciliwung Merdeka tentu membutuhkan kebersinambungan pendanaan, komitmen panjang dari para relawan, serta dukungan dari para stakeholder. Dengan begitu, setidaknya terdapat empat hal yang harus diperhatikan sebagai upaya pembangunan yang berkelanjutan. 
Pertama, Politics of Redistribution. Masalah lingkungan di Kali Ciliwung sebenarnya merupakan implikasi dari pembangunan Kota Jakarta yang tersentralisasi pada pertumbuhan ekonomi, bukan pemerataan kesejahteraan, apalagi perhatian pembangunan jangka panjang yang mempertimbangkan segenap aspek hidup manusia. Model pembangunan ini mengakar dalam kompleksnya persoalan kota ini, meliputi perumahan, fasilitas pelayanan transportasi, kebutuhan air bersih, sistem drainase, sanitasi, komposisi kependudukan, depedensi urbanisasi, dan sebagainya. Penanganan masalah melalui pengembangan komunitas seperti yang dilakukan Yayasan Ciliwung Merdeka tentu tidak akan berlangsung optimal bila tidak ditunjang upaya-upaya solusi strategis yang terpadu.

Oleh karenanya, pemikiran politics of redistribution dari Bradley (2003) dapat menjadi pertimbangan dalam penyelesaian masalah-masalah tersebut. Dalam gagasan ini, pemerintah sebagai salah satu aktor utama pembangunan memberikan daya dukung kepada pihak penunjang pembangunan, melalui distribusi pendanaan atau pun sebagian kewenangan, terutama dalam tataran operasional. Politics of redistribution ini juga dapat dituangkan dalam urban policy untuk menata aktivitas ekonomi, investasi publik, pelayanan, amenitas, dan kekuasaan politik dengan tujuan memberikan daya dukung bagi upaya pengentasan kemiskinan atau kesamaan akses kesejahteraan bagi segenap warga.

Kedua, komunikasi aktif di antara stakeholders. Politics of redistribution hanya bisa muncul bilamana telah dilakukan pemetaan peran dari aktor-aktor yang terkait dengan program-program Yayasan Ciliwung Merdeka. Aktor-aktor ini, seperti pihak pemerintah, lembaga donor, aktivis lingkungan, arsitek, pekerja sosial, serta warga setempat, perlu membangun komunikasi yang terpadu bersama Yayasan Ciliwung Merdeka. Apalagi berdasarkan data lapangan, YCM selama ini bergerak secara swadaya tanpa perhatian pemerintah atau pun lembaga donor yang mendukung secara berkelanjutan. Bahkan, keberadaan kampung-kampung sekitar Kali Ciliwung tersebut sangat rentan dengan kebijakan pemerintah yang berkeinginan melakukan normalisasi sungai dengan memperlebar pinggiran kali sepanjang 50m yang akan berimplikasi pada perubahan atau perpindahan lokasi pemukiman warga. Normalisasi ini menjadi perdebatan dan kerap ditentang warga sekitar dengan alasan akan mengubah pola mata pencaharian sebagian besar warga di sektor informal di wilayah dekat DAS (Daerah Aliran Singai). Untuk menyelesaikan kondisi ini, upaya dari Yayasan Ciliwung Merdeka saja tidak cukup. Pemerintah juga tetap membangun pola komunikasi bersama warga guna mensosialisasikan programnya secara utuh sehingga tidak menimbulkan kesalahpahaman.

Ketiga, pengembangan modal sosial. Berdiri sejak tahun 2000 dan disahkan menjadi lembaga berkekuatan hukum (yayasan) pada tahun 2008, merupakan salah satu modal legalitas yang penting bagi Yayasan Ciliwung Merdeka dalam menjalankan kiprahnya. Di sisi lain, YCM ini juga memiliki sebentuk modal sosial yang strategis, berupa akses hubungan yang intens dengan masyarakat setempat, yang merupakan buah dari kegiatan-kegiatan yang 
selama ini diterapkan. Modal sosial ini perlu dikembangkan dengan menjadikannya peluang posisi tawar kepada para aktor atau stakeholder yang berkeinginan untuk mengubah tatanan Kali Ciliwung, serta pembenahan pemukiman dan perekonomi warga. Dengan kata lain, YCM harus lebih berani mengadvokasi kepentingan warga.

Cara yang dapat dilakukan adalah dengan meningkatkan komunikasi dan kerja sama dengan komunitas-komunitas lain yang bergerak dalam bidang serupa, sehingga membangun suatu jejaring yang kuat dan padu sekaligus membangun inspirasi bagi kemungkinan gerakan serupa di lokasi-lokasi DAS lainnya. Jejaring ini dapat menjadi modal sosial yang lebih besar guna tampil sebagai wadah bersama yang berkekuatan advokasi penting di depan pemerintah atau pun mitra lainnya. Dengan demikian, sebagai upaya pembangunan yang berkelanjutan (sustainable development), penting memadukan berbagai sumber daya dalam pengembangan program-program YCM, seperti modal sosial, kultural, ekonomi, lingkungan, dan sebagainya. Sebab masing-masing modal tersebut memiliki keterbatasannya apabila tidak dipadukan satu sama lainnya (Ann Dale and Jenny Onyx, 2005).

Penekanan pada jaringan dan kepercayaan sosial sebagai pembentukan modal sosial yang sinergis pada level mikro menjadi solusi utama untuk mengatasi berbagai persoalan sosial dan ekonomi. Modal sosial ini beroperasi secara interpersonal dan tidak selalu beriringan dan sejalan dengan logika pertumbuhan ekonomi. Robert Putnam (1993) berpandangan bahwa pemanfaatan jaringan sosial ini merupakan aset potensial dalam sistem sosial dan politik yang berkelanjutan. Memang, jaringan yang tersusun secara informal ini tidak selalu memberikan perbaikan langsung dalam kesejahteraan. Namun, tanpa modal sosial, kemampuan personal (human capital) dan sumber daya materi (material resources) menjadi sia-sia. Bahkan modal sosial tidak selalu memerlukan sumber daya material dalam pembentukannya dan mampu terus tumbuh kuat seiring dengan pemanfaatannya. Putnam menekankan gagasan tentang sinergi sosial, yang menunjukkan bagaimana keterlibatan masyarakat mampu memperkuat lembaga-lembaga negara, sementara instansi pemerintahan yang efektif selalu berupaya menciptakan suatu lingkungan yang menekankan keterlibatan masyarakat yang aktif dan dinamis dalam pembangunan sosial.

Keempat, kebersinambungan relawan atau pekerja sosial yang berkomitmen. Yayasan Ciliwung Merdeka juga penting membangun kerjasama dengan institusi pendidikan seperti berbagai universitas dan lembaga-lembaga serupa yang terkait dengan upaya melibatkan pekerja sosial yang berkomitmen untuk mendorong perubahan sosial. Pekerja sosial ini penting bukan hanya dalam menunjang aktivitas kegiatan secara berkala, namun juga demi memberikan kesadaran sosial atas masalah-masalah nyata di masyarakat. Dipilihnya kampus dalam pola rekrutmen relawan ini terbilang strategis, karena universitas memiliki semangat yang sejalan dalam usaha pengabdian masyarakat, serta memungkinkan tumbuhnya gagasan-gagasan cerdas serta kreatif dalam pengembangan komunitas. 


\section{Kesimpulan}

Keberadaan Yayasan Ciliwung Merdeka (YCM) memiliki makna penting, bukan hanya bagi komunitas setempat, namun juga para stakeholder terkait, baik pihak pemerintah maupun swasta, dikarenakan perannya yang strategis dalam upaya pembangunan sosial. Selain menyelenggarakan program-program edukatif yang menunjang produktivitas komunitas dari segi ekonomi, YCM juga dapat berfungsi sebagai pendamping serta fasilitator yang menjembatani kepentingan masyarakat dengan pemerintah, terutama terkait penataan lingkungan, relokasi pemukiman serta rencana normalisasi sungai Ciliwung.

Secara konseptual, YCM telah melaksanakan gagasan pengembangan komunitas yang cukup ideal, di mana masyarakat setempat diberikan kebebasan dalam berpartisipasi membangun dirinya sendiri (asas kemandirian dan bottom up). YCM juga melakukan program-program dengan dimensi sosial yang luas, meliputi kegiatan kesehatan, pendidikan, pemberdayaan ekonomi, kesenian dan kebudayaan, berikut aksi peduli lingkungan. Hanya saja, dalam tataran yang lebih nyata, kegiatan-kegiatan partisipasi publik tersebut rentan untuk tidak berkesinambungan, dikarenakan perencanaan program yang belum menyeluruh, dukungan pendanaan, serta asas manfaat yang belum terakomodasi secara utuh.

Sementara itu, YCM sebenarnya telah memiliki modal sosial yang kuat, mengakar di masyarakat, mempunyai kepercayaan lewat pemberitaan positif media, serta berjuang melakukan aktivitasnya secara mandiri tanpa terlalu bergantung pada lembaga luar. Namun, YCM harus tetap realistis, bahwa kegiatan dan upaya advokasinya tidak dapat berlangsung bila modal sosial ini tidak diakumulasikan menjadi modal negoisasi atau posisi tawar dengan pemerintah ataupun stakeholder yang lebih luas. Bagaimana pun juga, persoalan di bantaran Kali Ciliwung bukanlah masalah komunitas setempat, melainkan menyangkut pula kepentingan sebagian besar warga Jakarta, oleh karena daerah aliran sungai ini sangat vital sebagai saluran air dan sanitasi wilayah secara keseluruhan.

Dengan kata lain, YCM perlu mentransformasi dirinya bukan hanya sebagai lembaga pendamping yang memfasilitasi program-program, namun juga harus menjadi pionir perubahan yang menyentuh banyak kalangan untuk mau membantu dan berpartisipasi menyelesaikan persoalan sosial tersebut. Di sisi lain, warga setempat juga perlu didorong untuk mengembangkan dirinya secara mandiri, tanpa terus-menerus bergantung kepada kehadiran YCM. 


\section{Bibliografi}

Dale, Ann and Jenny Onyx, A Dinamic Balance: Social Capital and Community Development. Toronto: UBC Press, 2005.

Du Bois, William D., Applying Sociology: Making A Better World. USA: Allyn \& Bacon, 2001.

Evans, Peter (ed.), State-Society Synergy: Government and Social Capital in Development. Berkeley: University of California, 1997.

Fukuyama, Francis, Social Capital and Development: The Coming Agenda. SAIS Review, Vol. XXII, No. 1, 2002.

Harris, Jonathan M (Ed.), A Survey of Sustainable Development: Social and Economic Dimensions. Washington: Island Press, 2001.

Martinussen, John, Society, State and Market: A Guide to Competing Theories of Development. London: Zed Books, 1997.

Muis, Rudolf Abdul, "Ciliwung Merdeka", dalam TERASMITRA: Berbagi Cerita Dari Mitra-Mitra GEF SGP Indonesia. Newsletter Mini. Global Environment Facility (GEF) SGP, Juni 2014.

Nikmah, Siti Khoirun, Pengabaian Pemerintah terhadap Eksistensi Penduduk pinggir Sungai: Wajah Pengelolaan Sungai di Indonesia. Laporan Penelitian. Jakarta: Infid, 2010.

Rangkuman laporan dan dokumen kegiatan Yayasan Ciliwung Merdeka 2008 - 2010.

Sen, Amartya, Rationally and Freedom. Oxford University Press, 2002.

Susilo, Rahmad Dwi, Sosiologi Lingkungan. Rajawali Press: Jakarta, 2012.

Soedjatmoko, Dimensi Manusia dalam Pembangunan. LP3ES: Jakarta, 1993. 